$\xi=$

\title{
Modeling the influence of cloudiness on diffuse horizontal irradiation under various sky conditions in Nigeria
}

\author{
Nwokolo Samuel Chukwujindu *, Ogbulezie Julie C. \\ Department of Physics, Faculty of Physical Sciences, University of Calabar, Nigeria, P.O. Box 2892, Calabar, Nigeria \\ *Corresponding author E-mail: nwokolosc@stud.unical.edu.ng
}

\begin{abstract}
In this study, modeling the influence of cloudiness on diffuse horizontal irradiation (DHI) in six tropical ecological zones in Nigeria (Latitude $4.75-13.067^{\circ} \mathrm{N}$ and Longitude $3.333-13.16^{\circ} \mathrm{E}$ ) using 22 -year data (July 1983- June 2005) was analysed for all sky and clear sky conditions. The result revealed that the absorption of DHI in the global horizontal irradiation (GHI) portion of the solar spectrum is greatly enhanced in the Southern tropical zones as a result of heavy presence of smog, cloudiness, and high water vapour parameters such as relative humidity, dew point temperature and precipitable water thereby increasing the diffuse fraction in the zone. However, in the Northern tropical zones, the absorption of DHI in the GHI portion of the solar spectrum lowered due to presence of low smog, cloudiness and low water vapour parameters thereby reducing the diffuse fraction in the region. The quadratic regression correlation model developed deeming from the model performance test indicates that the proposed model could be used to estimate DHI accurately over the six tropical ecological zones in Nigeria and other locations with comparable sky condition to Nigeria.
\end{abstract}

Keywords: Equatorial Line; Diffuse Fraction; Clearness Index; Diffuse Horizontal Irradiation; Sky Conditions

\section{Introduction}

Diffuse horizontal irradiation (DHI) is the component of global horizontal irradiation (GHI) reaching the earth's surface after having been scattered from the direct horizontal irradiation (BHI) by molecules, aerosols or suspended particular matter such as black carbon, organic carbon, dust and sea salt in the atmosphere. DHI plays an important role in determining the gross primary productivity, net ecosystem exchange of carbon dioxide, light use efficiency, changing colour of the sky and baseline for estimating and understanding DHI parameters such as DHI and GHI on the titles surfaces, diffuse Photosynthetically active radiation (PAR), near infrared radiation (NIR), reflected BHI and GHI.

Therefore, the accurate determination and clear understanding of the DHI parameters is required for many applications such as energy management, solar energy, light studies, architectural research, hydrological process and biometeorology, crop production, remote sensing of vegetable and carbon cycle modelling, development of thermal and electrical solar energy devices [1-4].

DHI arises as a result of the interaction between the solar radiation incident on the top of the earth's atmosphere and the matter within it. Thus, understanding how this radiometric flux interact with the matter within it and relates with its immediate environment thereby influencing diffuse light availability for energy, sky colour, agricultural, material and technological production and utilization for man's need is of almost important for modeling and estimating DHI in a particular geographical environment.

Measurement of DHI is often performed in many parts of the world by mounting a pyranometer on the axis of the ring on a roof top so as to receive only DHI, and the ring is normally adjusted regularly so as to ensure that the direct irradiance does not reach the pyranometer.
In spite of the enormous significance of DHI, there is no standard weather station able to measure this radiation component in Nigeria and often there is no data available in the location of interest except National Aeronautics and Space Administration (NASA) atmospheric science data among others satellite radiometric agencies across the globe.

To overcome these shortcomings, different estimation models have been proposed in different locations across the world [5-16]. It is therefore imperative to analyse DHI using GHI and clearness index obtained from NASA data. This will produce DHI data as a baseline for further scientific, environmental and atmospheric research without the substantial cost of the instrumentation network that would otherwise be needed [17-19]. The aim of this research paper is to develop an empirical model for estimating DHI in six tropical ecological zones in Nigeria.

\section{Methodology}

\subsection{Acquisition of data and study area}

The long term monthly mean daily diffuse horizontal irradiation (DHI), global horizontal irradiation (GHI), clearness index for clear sky $\left(\mathrm{k}_{\mathrm{t}}\right)$ for the period of 1983-2005 for the selected state capitals and locations whose tropical ecological zones, coordinates and elevations listed in Table 1 and Fig. 1 were obtained from the National Aeronautics and Space Administration (NASA) atmospheric science data center. The GHI and DHI data measured in $\mathrm{kwhm}^{-2} \mathrm{day}^{-1}$ were converted to $\mathrm{MJm}^{-2} \mathrm{day}^{-1}$ using a factor of 3.6. The details of the study area are found in Nwokolo and Ogbulezie [19]. 
Table 1: States, State Capitals, Coordinates and Tropical Ecological Zones for the Selected Stations in Nigeria

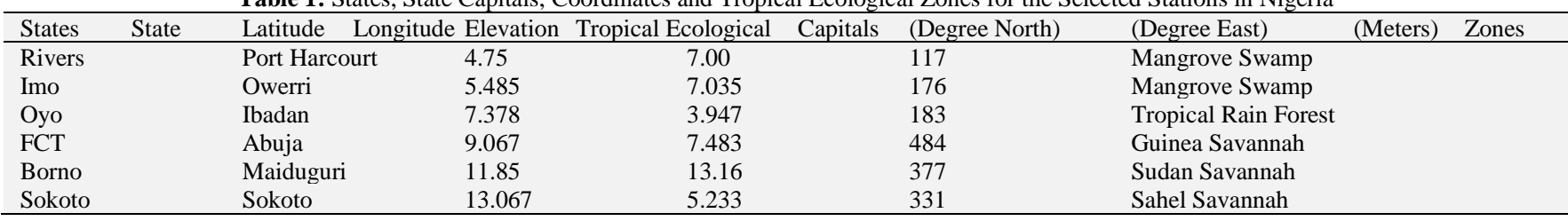

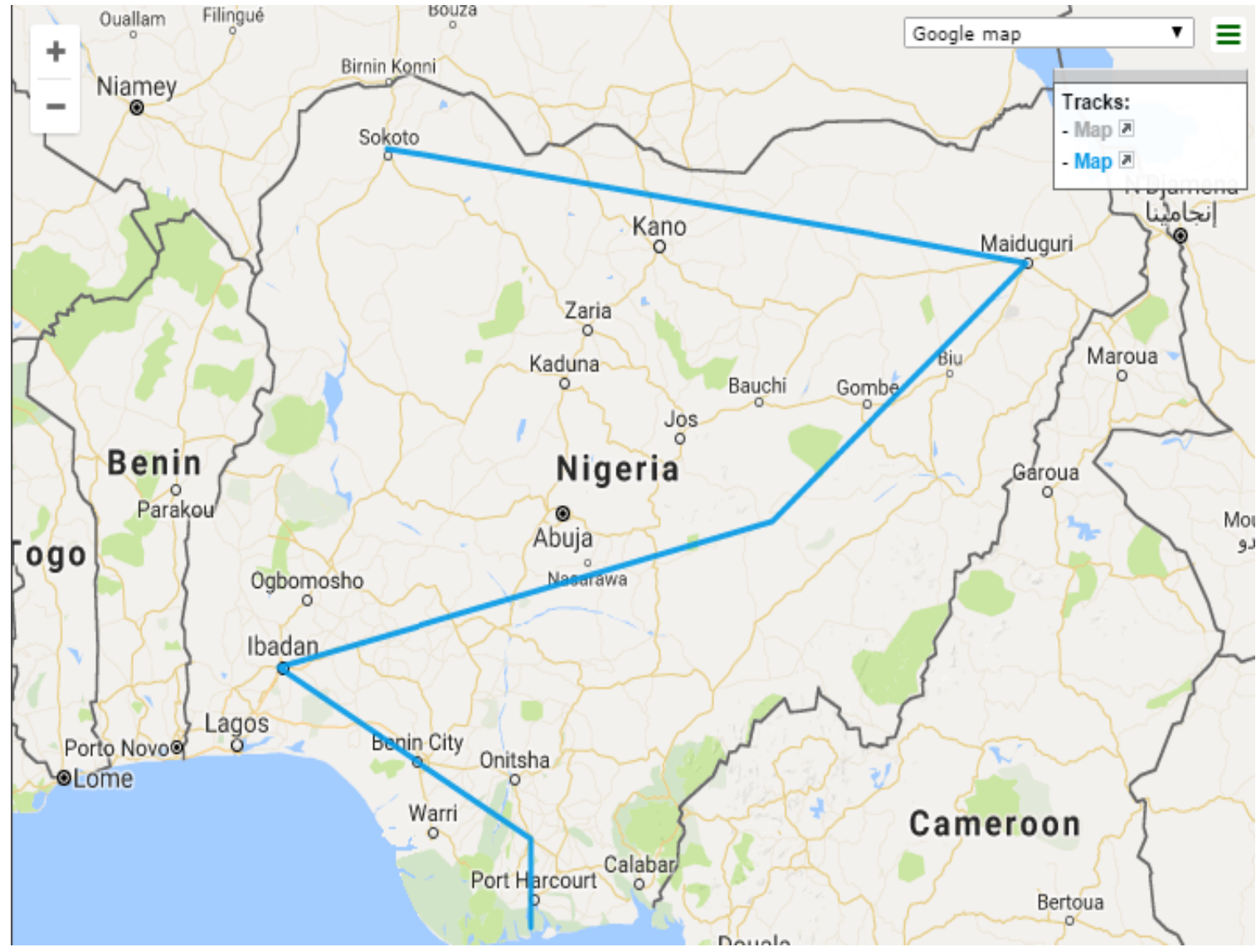

Fig. 1: Map of Nigeria Showing the Study Stations.

\subsection{Model development}

The modelling of DHI involves the correlation of monthly mean daily DHI to meteorological data such as GHI and clearness index. Several researchers proposed simple quadratic and polynomial equations which relates DHI fraction and clearness index [5-10]. In order to generate an appropriate model for the study stations in addition to previous models, a quadratic correlation expression which is based on meteorological parameters such as DHI, GHI and clearness index for all sky and clear sky conditions $\left(\mathrm{k}_{\mathrm{t}}\right)$ are investigated in this research paper in the form:

$$
\frac{D H I}{G H I}=a+b k_{t}+c k_{t}^{2}
$$

Where $a, b$, and $c$ are the empirical coefficients, DHI and GHI retain their usual meaning and $\mathrm{k}_{\mathrm{t}}$ the clearness index is given as follows:

$$
k_{t}=\frac{G H I}{H_{o}}
$$

Where $\mathrm{H}_{\mathrm{o}}$ is the extraterrestrial solar radiation on the horizontal surface is given as follows:

$$
H_{O}=\frac{24}{\pi} I S C\left(\begin{array}{l}
1 \\
+0.033 \cos \frac{360 n}{365}
\end{array}\right) \times\left(\begin{array}{l}
\cos \varphi \cos \delta \sin \omega_{S} \\
2 \pi \omega_{S} \\
+\frac{260}{360} \sin \sin \delta
\end{array}\right)
$$

Where $I_{S C}$ the solar constant, $\varphi$ is the latitude, $\delta$ is the solar declination and $n$ the number of days of the year starting from first January. The daily extraterrestrial solar radiation is the solar radiation intercepted by horizontal surface during a day without the atmosphere and hourly extraterrestrial radiation has similar definition. For a given month, the solar declination $(\delta)$ and the mean sunrise hour angle $\left(\omega_{S}\right)$ can be evaluated by the following equations (4) and (5) respectively.

$\delta=23.45 \sin \left[\frac{360(n+284)}{365}\right]$

$\omega_{S}=\cos ^{-1}[-\tan \delta \tan \varphi]$

A computer statistical software program (IBM SPSS 22) was used to compute the regression constants at $95 \%$ confidence level employed to obtaining the correlation coefficient (R), coefficient of determination $\left(\mathrm{R}^{2}\right)$, adjusted coefficient of determination $\left(R_{a}^{2}\right)$ and standard error of estimation. 


\subsection{Estimation metrics}

To determine the error and performance of the predictive models, Willmott [20] suggested mean bias error (MBE), mean percentage error (MPE) and root mean square error (RMSE) as good statistical indicator for evaluating the error between the observed and predicted (model) values. These relations are given as:

$$
\begin{aligned}
& M B E=\frac{1}{n} \sum_{i=1}^{n}\left(O_{i}-P_{i}\right) \\
& M P E=\frac{1}{n} \sum_{i=1}^{n}\left(\frac{O_{i}-P_{i}}{O_{i}}\right) \times 100 \\
& R M S E=\sqrt{\frac{1}{n} \sum_{i=1}^{n}\left(O_{i}-P_{i}\right)^{2}}
\end{aligned}
$$

Where $\mathrm{O}_{\mathrm{i}}$ and $\mathrm{P}_{\mathrm{i}}$ are the observed and predicted DHI and other symbols retain their usual meaning.

\section{Results and discussions}

\subsection{Variation of atmospheric parameters}

The monthly mean daily GHI, DHI and Clearness Index $\left(\mathrm{K}_{\mathrm{t}}\right)$ for clear sky and all sky conditions for Port Harcourt, Owerri, Ibadan, Abuja, Maiduguri and Sokoto representing the six tropical ecological zones are presented in Table 2. The monthly and seasonal variations are observed for DHI and clearness index for clear sky and all sky conditions are shown in Fig. 2. It is also observed that DHI increases with latitude from Lat. $4.4-13.03^{\circ} \mathrm{N}$ along the typical ecological zones from Northern tropical zones of Sahel Savannah (FNZSS) of Sokoto to the far Southern tropical zones of mangrove swamp (FSZMS) of Port Harcourt as expected for a tropical sits Burari [21]. This variation was mainly due to trends in cloudiness and associated atmospheric moisture with the movement of the Hadley cell circulation system along the equatorial line.

The Nigeria weather condition is classified into two seasons: Dry and wet season. Dry reason is attributed to the influence of inter tropical convergence zone (ITCZ) producing tropical Continental (TC) associated with dry and dusty North - East winds (easterlies) which blows from the Sahara Desert and finally prevail over Nigeria; thus producing the dry season conditions. The implication is that there is a prolonged dry season in the far North, while the far south undergoes short dry periods annually.

With the movement of the ITCZ into the Northern hemisphere, the rain-bearing south westerlies prevail as far inland as possible to bring rainfall during the rainy season. This results to prolonged rainy season in the far South while the far North undergoes short rainy periods annually [22].

The dry season is from November to March while the wet season start in April and ends in October. The rainy season is characterized by overcast and heavy rain clouds. This give rise to the relatively high DHI and low clearness index as observed between the months of May-October compared to the dry season months for all sky condition while clearness index is relatively high under clear sky weather as shown in Fig. 2.

The lowest DHI of $4.46 \mathrm{MJm}^{-2} \mathrm{day}^{-1}$ occurred in the months of November and December for Sokoto while the lowest clearness index for clear sky weather registered 0.52 in the months of February and November for Owerri and Ibadan. This is due to the presence of relatively low clouds and dry season as low cloud absorb more BHI than DHI in the solar spectrum thereby producing low magnitude of DHI received in the zone. The clearness index for all sky recorded 0.33 in the month of September for Port Harcourt. This is due to the presence of heavy smog and clouds, and prolonged rainfall as clouds absorb more DHI component than in the BHI component thereby producing low clearness index in the zone. These results are comparable to the report of Theophile and Rene [10] in Cameroun.

The highest values of DHI of $8.28 \mathrm{MJm}^{-2} \mathrm{day}^{-1}$ recorded in the months of March and April for Port Harcourt. This is because clouds absorbed more DHI component of radiation than BHI as a result of heavy smog, low clearness index and prolonged rainfall thereby enhancing the amount of DHI received in the zone. The highest clearness index for all sky conditions is 0.69 recorded in the month of February for Sokoto. However, Sokoto registered the highest value of clearness index of 0.60 under clear sky condition in the months of March, April and June. This could be attributed to the presence of low smog and clouds with associated dry harmattan breeze that blows and prevailed over Sokoto and its environs.

\begin{tabular}{|c|c|c|c|c|c|}
\hline Month & $\begin{array}{c}\text { GHI } \\
\left(\mathrm{MJm}^{-2} \mathrm{day}^{-1}\right)\end{array}$ & $\begin{array}{l}k_{t} \\
\text { All Sky }\end{array}$ & $\begin{array}{l}k_{t} \\
\text { Clear Sky }\end{array}$ & $\begin{array}{l}\text { Obs DHI } \\
\left(\mathrm{MJm}^{-2} \mathrm{day}^{-1}\right)\end{array}$ & $\begin{array}{l}\text { Pre DHI } \\
\left(\mathrm{MJm}^{-2} \mathrm{day}^{-1}\right)\end{array}$ \\
\hline JANUARY & 18.72 & 0.54 & 0.53 & 6.73 & 6.78 \\
\hline FEBUARY & 18.86 & 0.52 & 0.53 & 7.49 & 7.42 \\
\hline MARCH & 17.28 & 0.46 & 0.55 & 8.28 & 8.11 \\
\hline APRIL & 16.56 & 0.44 & 0.58 & 8.28 & 8.11 \\
\hline MAY & 15.23 & 0.42 & 0.57 & 7.85 & 7.87 \\
\hline JUNE & 12.74 & 0.36 & 0.55 & 7.42 & 7.53 \\
\hline JULY & 11.66 & 0.33 & 0.55 & 7.31 & 7.37 \\
\hline AUGUST & 12.31 & 0.34 & 0.57 & 7.67 & 7.65 \\
\hline SEPTEMBER & 12.35 & 0.33 & 0.58 & 7.88 & 7.75 \\
\hline OCTOBER & 13.25 & 0.36 & 0.59 & 7.78 & 7.81 \\
\hline NOVEMBER & 15.16 & 0.44 & 0.55 & 7.38 & 7.48 \\
\hline DECEMBER & 17.82 & 0.53 & 0.54 & 6.66 & 6.79 \\
\hline AVERAGE & 15.16 & 0.42 & 0.56 & 7.56 & 7.55 \\
\hline SUM & 181.94 & 5.07 & 6.69 & 90.72 & 90.65 \\
\hline
\end{tabular}

Table 2: A) Monthly Mean Daily Values of Global Horizontal Irradiation (GHI), Diffuse Horizontal Irradiation (DHI), Clearness Index (Kt) Under All Sky Conditions and Clear Sky, Observed (Obs) and Predicted (Pre) Values for Port Harcourt. 
Table 2: B) Monthly Mean Daily Values of Global Horizontal Irradiation (GHI), Diffuse Horizontal Irradiation (DHI), Clearness Index (K $)_{t}$ Under All Sky Conditions and Clear Sky, Observed (Obs) and Predicted (Pre) Values (DHI) for Owerri.

\begin{tabular}{|c|c|c|c|c|c|}
\hline Month & $\begin{array}{c}\mathrm{GHI} \\
\left(\mathrm{MJm}^{-2} \mathrm{day}^{-1}\right)\end{array}$ & $\begin{array}{c}k_{t} \\
\text { All Sky }\end{array}$ & $\begin{array}{l}k_{t} \\
\text { Clear Sky }\end{array}$ & $\begin{array}{l}\text { Obs DHI } \\
\left(\mathrm{MJm}^{-2} \mathrm{day}^{-1}\right)\end{array}$ & $\begin{array}{l}\text { Pre DHI } \\
\left(\mathrm{MJm}^{-2} \mathrm{day}^{-1}\right)\end{array}$ \\
\hline JANUARY & 19.91 & 0.58 & 0.54 & 6.23 & 6.24 \\
\hline FEBUARY & 20.12 & 0.56 & 0.52 & 7.09 & 7.01 \\
\hline MARCH & 19.15 & 0.51 & 0.55 & 8.03 & 7.82 \\
\hline APRIL & 18.32 & 0.49 & 0.58 & 8.21 & 7.98 \\
\hline MAY & 16.99 & 0.47 & 0.56 & 7.85 & 7.87 \\
\hline JUNE & 15.52 & 0.44 & 0.55 & 7.63 & 7.77 \\
\hline JULY & 13.86 & 0.39 & 0.55 & 7.67 & 7.76 \\
\hline AUGUST & 13.57 & 0.37 & 0.58 & 7.92 & 7.89 \\
\hline SEPTEMBER & 14.18 & 0.38 & 0.59 & 8.17 & 8.04 \\
\hline OCTOBER & 15.37 & 0.42 & 0.58 & 7.85 & 7.93 \\
\hline NOVEMBER & 17.42 & 0.51 & 0.53 & 7.02 & 7.21 \\
\hline DECEMBER & 19.04 & 0.57 & 0.53 & 6.16 & 6.27 \\
\hline AVERAGE & 16.96 & 0.47 & 0.56 & 7.49 & 7.48 \\
\hline SUM & 203.47 & 5.68 & 6.66 & 89.82 & 89.81 \\
\hline
\end{tabular}

Table 2: C) Monthly Mean Daily Values of Global Horizontal Irradiation (GHI), Diffuse Horizontal Irradiation (DHI), Clearness Index (K ( $_{\mathrm{t}}$ Under All Sky Conditions and Clear Sky, Observed (Obs) and Predicted (Pre) Values (DHI) for Ibadan.

\begin{tabular}{|c|c|c|c|c|c|}
\hline Month & $\begin{array}{c}\text { GHI } \\
\left(\mathrm{MJm}^{-2} \mathrm{day}^{-1}\right)\end{array}$ & $\begin{array}{c}k_{t} \\
\text { All Sky }\end{array}$ & $\begin{array}{l}k_{t} \\
\text { Clear Sky }\end{array}$ & $\begin{array}{l}\text { Obs DHI } \\
\left(\mathrm{MJm}^{-2} \mathrm{day}^{-1}\right)\end{array}$ & $\begin{array}{l}\text { Pre DHI } \\
\left(\mathrm{MJm}^{-2} \mathrm{day}^{-1}\right)\end{array}$ \\
\hline JANUARY & 20.45 & 0.60 & 0.55 & 5.87 & 6.56 \\
\hline FEBUARY & 20.66 & 0.57 & 0.53 & 6.80 & 7.17 \\
\hline MARCH & 20.05 & 0.53 & 0.55 & 7.78 & 7.74 \\
\hline APRIL & 18.90 & 0.50 & 0.56 & 8.17 & 7.90 \\
\hline MAY & 17.75 & 0.48 & 0.56 & 7.85 & 7.82 \\
\hline JUNE & 16.34 & 0.45 & 0.54 & 7.70 & 7.79 \\
\hline JULY & 14.87 & 0.41 & 0.55 & 7.81 & 7.85 \\
\hline AUGUST & 14.08 & 0.38 & 0.57 & 8.03 & 8.01 \\
\hline SEPTEMBER & 15.08 & 0.40 & 0.58 & 8.21 & 8.16 \\
\hline OCTOBER & 16.45 & 0.45 & 0.57 & 7.74 & 7.84 \\
\hline NOVEMBER & 18.40 & 0.54 & 0.52 & 6.70 & 6.92 \\
\hline DECEMBER & 19.66 & 0.59 & 0.55 & 7.76 & 6.47 \\
\hline AVERAGE & 17.72 & 0.49 & 0.55 & 7.37 & 7.36 \\
\hline SUM & 212.69 & 5.90 & 6.63 & 88.42 & 88.28 \\
\hline
\end{tabular}

Table 2: D) Monthly Mean Daily Values of Global Horizontal Irradiation (GHI), Diffuse Horizontal Irradiation (DHI), Clearness Index (K $\mathrm{K}_{\mathrm{t}}$ Under All Sky Conditions and Clear Sky, Observed (Obs) and Predicted (Pre) Values (DHI) for Abuja.

\begin{tabular}{|c|c|c|c|c|c|}
\hline Month & $\begin{array}{c}\mathrm{GHI} \\
\left(\mathrm{MJm}^{-2} \mathrm{day}^{-1}\right)\end{array}$ & $\begin{array}{c}k_{t} \\
\text { All Sky }\end{array}$ & $\begin{array}{l}k_{t} \\
\text { Clear Sky }\end{array}$ & $\begin{array}{l}\text { Obs DHI } \\
\left(\mathrm{MJm}^{-2} \mathrm{day}^{-1}\right)\end{array}$ & $\begin{array}{l}\text { Pre DHI } \\
\left(\mathrm{MJm}^{-2} \mathrm{day}^{-1}\right)\end{array}$ \\
\hline JANUARY & 21.17 & 0.66 & 0.59 & 4.93 & 4.99 \\
\hline FEBUARY & 21.92 & 0.63 & 0.57 & 5.94 & 6.00 \\
\hline MARCH & 22.57 & 0.61 & 0.57 & 6.88 & 6.74 \\
\hline APRIL & 21.82 & 0.58 & 0.59 & 7.70 & 7.34 \\
\hline MAY & 20.09 & 0.54 & 0.57 & 7.78 & 7.75 \\
\hline JUNE & 18.22 & 0.49 & 0.56 & 7.81 & 7.91 \\
\hline JULY & 15.98 & 0.43 & 0.57 & 8.06 & 8.09 \\
\hline AUGUST & 15.08 & 0.40 & 0.59 & 8.24 & 8.17 \\
\hline SEPTEMBER & 17.03 & 0.46 & 0.58 & 8.14 & 8.22 \\
\hline OCTOBER & 19.12 & 0.54 & 0.56 & 7.09 & 7.14 \\
\hline NOVEMBER & 21.53 & 0.66 & 0.60 & 5.08 & 5.07 \\
\hline DECEMBER & 21.10 & 0.67 & 0.61 & 4.50 & 4.43 \\
\hline AVERAGE & 19.64 & 0.56 & 0.58 & 6.85 & 6.82 \\
\hline SUM & 235.62 & 6.67 & 6.96 & 82.15 & 81.85 \\
\hline
\end{tabular}

Table 2: E) Monthly Mean Daily Values of Global Horizontal Irradiation (GHI), Diffuse Horizontal Irradiation (DHI), Clearness Index (K $\mathrm{t}_{\mathrm{t}}$ Under All Sky Conditions and Clear Sky, Observed (Obs) and Predicted (Pre) Values (DHI) for Maiduguri.

\begin{tabular}{|c|c|c|c|c|c|}
\hline Month & $\begin{array}{c}\text { GHI } \\
\left(\mathrm{MJm}^{-2} \mathrm{day}^{-1}\right)\end{array}$ & $\begin{array}{c}k_{t} \\
\text { All Sky }\end{array}$ & $\begin{array}{l}k_{t} \\
\text { Clear Sky }\end{array}$ & $\begin{array}{l}\text { Obs DHI } \\
\left(\mathrm{MJm}^{-2} \mathrm{day}^{-1}\right)\end{array}$ & $\begin{array}{l}\text { Pre DHI } \\
\left(\mathrm{MJm}^{-2} \mathrm{day}^{-1}\right)\end{array}$ \\
\hline JANUARY & 20.20 & 0.64 & 0.59 & 4.90 & 5.14 \\
\hline FEBUARY & 22.68 & 0.66 & 0.60 & 5.22 & 5.16 \\
\hline MARCH & 24.12 & 0.66 & 0.61 & 6.08 & 5.75 \\
\hline APRIL & 23.83 & 0.63 & 0.60 & 7.09 & 6.57 \\
\hline MAY & 22.90 & 0.60 & 0.60 & 7.24 & 6.95 \\
\hline JUNE & 21.49 & 0.57 & 0.59 & 7.38 & 7.37 \\
\hline JULY & 19.55 & 0.52 & 0.58 & 7.88 & 7.95 \\
\hline AUGUST & 18.50 & 0.49 & 0.57 & 8.24 & 8.18 \\
\hline SEPTEMBER & 20.05 & 0.54 & 0.57 & 7.00 & 7.63 \\
\hline OCTOBER & 21.20 & 0.61 & 0.59 & 6.19 & 6.30 \\
\hline NOVEMBER & 21.02 & 0.66 & 0.61 & 4.82 & 4.95 \\
\hline DECEMBER & 19.26 & 0.63 & 0.58 & 4.79 & 5.14 \\
\hline AVERAGE & 21.23 & 0.60 & 0.59 & 6.45 & 6.43 \\
\hline SUM & 254.81 & 7.23 & 7.09 & 77.44 & 77.13 \\
\hline
\end{tabular}


Table 2: F) Monthly Mean Daily Values of Global Horizontal Irradiation (GHI), Diffuse Horizontal Irradiation (DHI), Clearness Index (K ${ }_{\mathrm{t}}$ ) Under All Sky Conditions and Clear Sky, Observed (Obs) and Predicted (Pre) Values for Sokoto.

\begin{tabular}{|c|c|c|c|c|c|}
\hline Month & $\begin{array}{c}\mathrm{GHI} \\
\left(\mathrm{MJm}^{-2} \mathrm{day}^{-1}\right)\end{array}$ & $\begin{array}{c}k_{t} \\
\text { All Sky }\end{array}$ & $\begin{array}{l}k_{t} \\
\text { Clear Sky }\end{array}$ & $\begin{array}{l}\text { Obs DHI } \\
\left(\mathrm{MJm}^{-2} \mathrm{day}^{-1}\right)\end{array}$ & $\begin{array}{l}\text { Pre DHI } \\
\left(\mathrm{MJm}^{-2} \mathrm{day}^{-1}\right)\end{array}$ \\
\hline JANUARY & 19.69 & 0.65 & 0.60 & 4.64 & 4.97 \\
\hline FEBUARY & 23.08 & 0.69 & 0.63 & 4.68 & 4.90 \\
\hline MARCH & 24.73 & 0.68 & 0.64 & 5.62 & 5.48 \\
\hline APRIL & 25.74 & 0.68 & 0.64 & 6.30 & 5.78 \\
\hline MAY & 25.31 & 0.66 & 0.63 & 6.52 & 6.04 \\
\hline JUNE & 24.88 & 0.65 & 0.64 & 6.44 & 6.09 \\
\hline JULY & 22.54 & 0.59 & 0.62 & 7.34 & 7.14 \\
\hline AUGUST & 20.63 & 0.55 & 0.60 & 7.99 & 8.05 \\
\hline SEPTEMBER & 21.64 & 0.59 & 0.59 & 7.09 & 7.00 \\
\hline OCTOBER & 21.71 & 0.64 & 0.60 & 5.72 & 5.76 \\
\hline NOVEMBER & 20.84 & 0.67 & 0.62 & 4.46 & 4.77 \\
\hline DECEMBER & 18.90 & 0.64 & 0.60 & 4.46 & 4.83 \\
\hline AVERAGE & 22.47 & 0.64 & 0.62 & 5.94 & 5.90 \\
\hline SUM & 269.68 & 7.69 & 7.41 & 71.28 & 70.81 \\
\hline
\end{tabular}

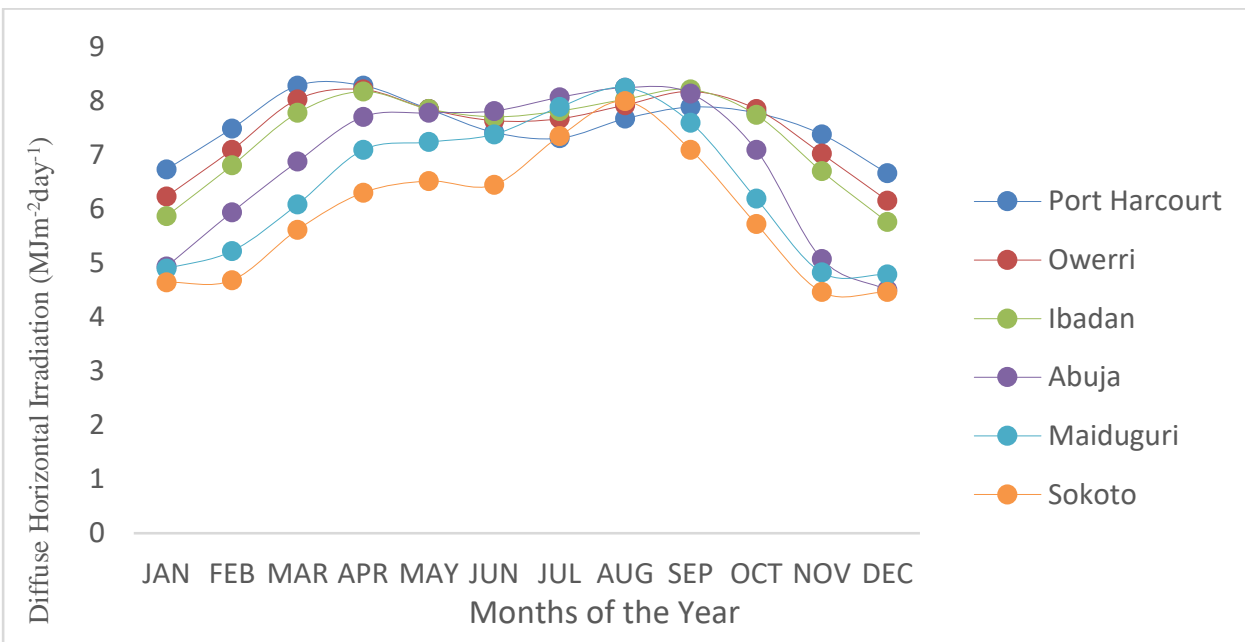

Fig. 2: A) Comparison between Observed Diffuse Horizontal Irradiation for Port Harcourt, Owerri, Ibadan, Abuja, Maiduguri and Sokoto.

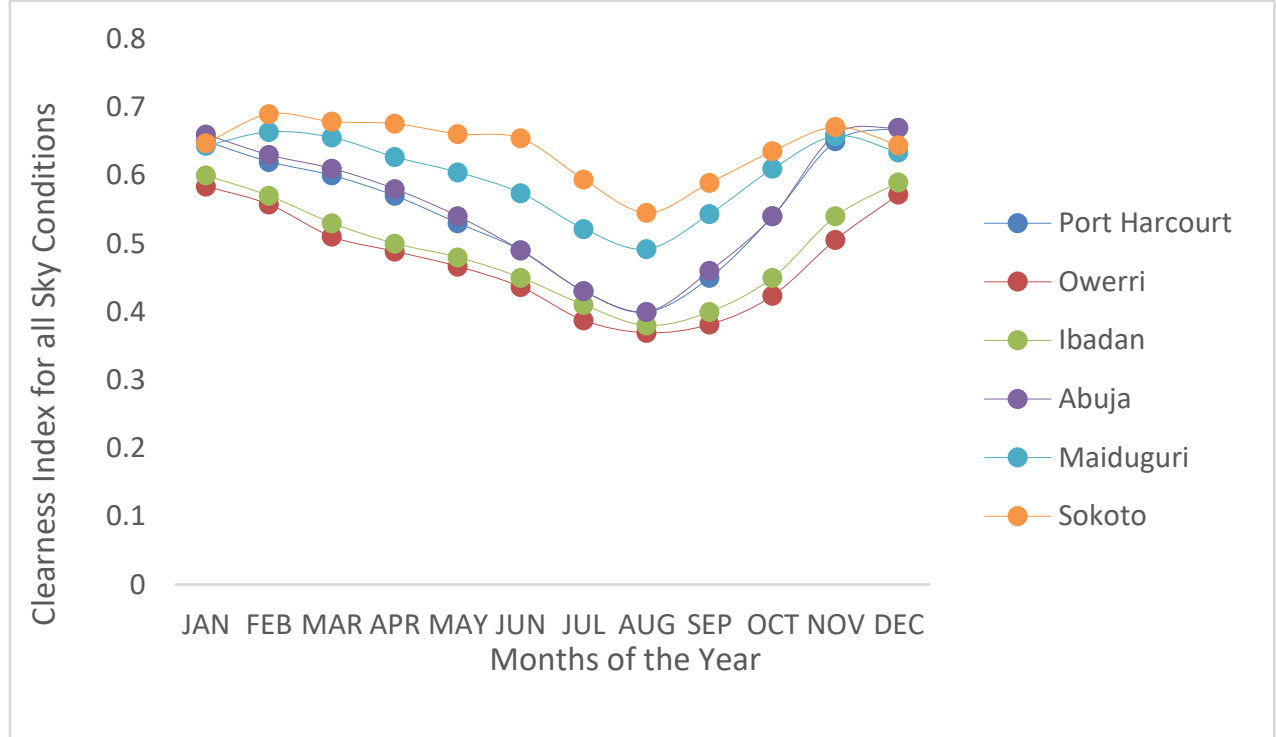

Fig. 2: B) Variation of Clearness Index for All Sky Conditions with the Months of the Year for Port Harcourt, Owerri, Ibadan, Abuja, Maiduguri and Sokoto. 


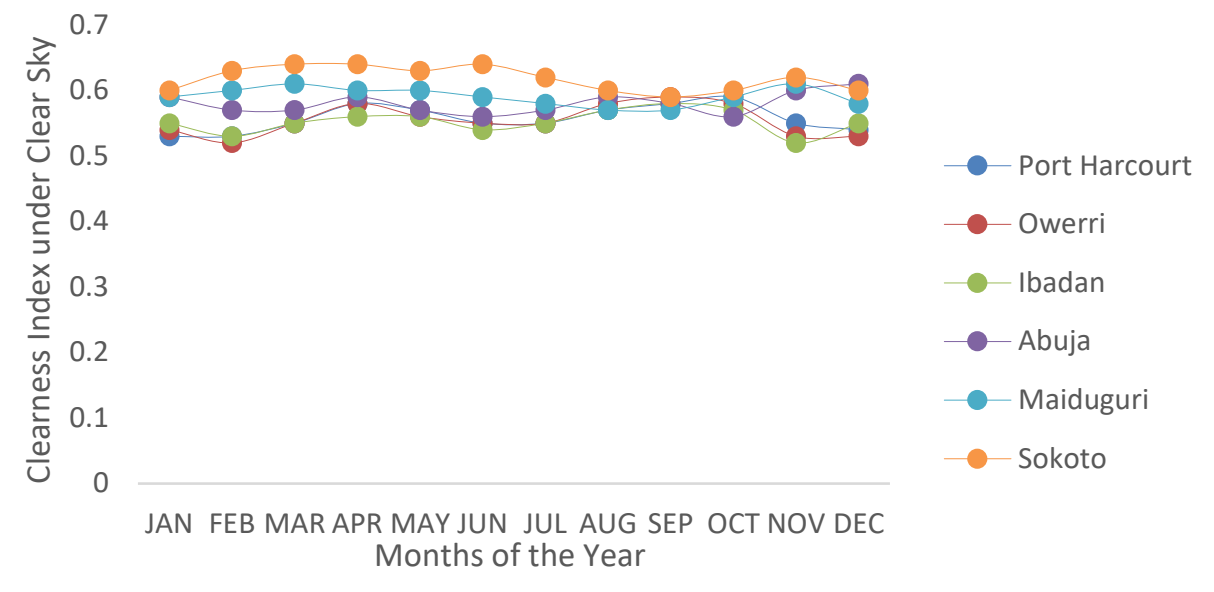

Fig. 2: C) Variation of Clearness Index Under Clear Sky with Months of the Year for Port Harcourt, Owerri, Ibadan, Abuja, Maiduguri and Sokoto.

\subsection{Influence of clearness index on diffuse horizontal irradiance (DHI)}

Similar weather variation and characteristics range (0.538-0.816) were observed between the annual clearness index under all sky conditions and DHI for Port Harcourt, Owerri, Ibadan, Abuja, Maiduguri and Sokoto as show in Table 3. This reveals that DHI is optimally controlled by clearness index under all sky conditions in Nigeria in spite of the low correlation obtained under clear sky. The minimum correlation of 0.538 was reported for Sokoto in the FSZNS whereas in the FSZMS 0.8164 was registered for Port Harcourt. This discrepancy is due to increase in monthly mean value of DHI in the growing season where the clearness index reduced greatly in FSZMS compared to FNZSS under all sky conditions, thus, the absorption of DHI compared to BHI in the global horizontal irradiation (GHI) portion of the solar spectrum is great- ly enhanced in the FSZMS of Port Harcourt and slightly reduced to the North Central and finally decreased greatly in the FNZSS of Sokoto.

Remarkable decreases in correlation were found on clear sky conditions as compared to all sky conditions from the Southern part of Nigeria to FNZSS of Sokoto. The minimum correlation of 0.0023 was registered for Sokoto while the maximum correlation of 0.5577 was reported for Owerri. This deviation could be attributed to further decrease of DHI compared to BHI in the global horizontal irradiation (GHI) portion of the solar spectrum from the Southern Nigeria to the FNZSS of Sokoto as a result of the increase in cloudiness and associated atmospheric moisture as clouds absorbs more mixture content contributed by heavy clouds from the harmattan breeze that flows and prevailed over Northern tropical zones thereby culminating into lower correlation between the DHI and clearness index under clear sky conditions for all the zones.

Table 3: Statistical Results for Estimating the Influence of Clearness Index on Diffuse Horizontal Irradiation in Terms of Their Capability for Predicting the Diffuse Horizontal Irradiation for Port Harcourt, Owerri, Ibadan, Abuja, Maiduguri and Sokoto

\begin{tabular}{|c|c|c|c|c|}
\hline Locations & Sky Conditions & $\mathrm{b}_{0}$ & $\mathrm{~b}_{1}$ & $\mathrm{R}^{2}$ \\
\hline \multirow[t]{2}{*}{ Port Harcourt } & All Sky & 14.273 & -13.50 & 0.816 \\
\hline & Clear Sky & -1.874 & 16.922 & 0.4369 \\
\hline \multirow[t]{2}{*}{ Owerri } & All Sky & 10.814 & -7.031 & 0.5577 \\
\hline & Clear Sky & -5.400 & 23.21 & 0.5767 \\
\hline \multirow[t]{2}{*}{ Ibadan } & All Sky & 12.059 & -9.542 & 0.6915 \\
\hline & Clear Sky & -7.4955 & 26.902 & 0.2838 \\
\hline \multirow[t]{2}{*}{ Abuja } & All Sky & 14.076 & -13.008 & 0.7956 \\
\hline & Clear Sky & 35.705 & -49.757 & 0.3333 \\
\hline \multirow[t]{2}{*}{ Maiduguri } & All Sky & 18.049 & -19.256 & 0.7411 \\
\hline & Clear Sky & 33.121 & -45.136 & 0.2365 \\
\hline \multirow[t]{2}{*}{ Sokoto } & All Sky & 19.008 & -20.404 & 0.5376 \\
\hline & Clear Sky & 7.8579 & -3.1059 & 0.0023 \\
\hline
\end{tabular}

\subsection{Correlation analysis}

The following observations were deduced from the analysis of the result presented in Table 2. This is comparable to the result reported Theophile and Rene [10]. From the Table 2, it can be seen that the annual DHI for Port Harcourt, Owerri, Ibadan, Abuja, Maiduguri and Sokoto are $90.72 \mathrm{MJm}^{-2} \mathrm{day}^{-1}, 89.82 \mathrm{MJm}^{-2} \mathrm{day}^{-1}, 88.42$ $\mathrm{MJm}^{-2} \mathrm{day}^{-1}, 82.15 \mathrm{MJm}^{-2}$ day $^{-1}, 77.44 \mathrm{MJm}^{-2} \mathrm{day}^{-1}$ and $71.28 \mathrm{MJm}^{-}$ ${ }^{2} \mathrm{day}^{-1}$. The radiation obtained throughout the year is high under all sky conditions for six tropical ecological zones in Nigeria. This indicates that crops have high potential for gross primary productivity, net ecosystem exchange of carbon dioxide and light use efficiency at any time of the months in the growing season (April
- October) provided other atmospheric conditions such as soil moisture content, temperature and relative humidity are favourable.

The empirical constants of the proposed model varied for $b_{o}, b_{1}$, $\mathrm{b}_{2}, \mathrm{R}, \mathrm{R}^{2}, R_{a}^{2}$ and standard error of estimation from one tropical ecological zone to another under various sky conditions as shown in Table 4. This could be attributed to the seasonal variation of DHI principally caused by the influence of latitude, presence of smog, clearness index, relative humidity, rainy and dry seasons, and the movement of the Hadley cell circulation system along the equatorial line in the atmosphere which differs from one tropical ecological zone to another. 
The intercept $b_{o}$ ranged from $0.907-2.132$; slope, $b_{2}$, between $0.721--4.750$ and $b_{2}$ ranged of $0.195-2.852$ were obtained from the correlations under all sky conditions. These values are within the range observed by several researchers [9-10, 14-15]. However, the values obtained for clear sky conditions were higher than all sky conditions. This is because DHI is greatly enhanced under all sky conditions than clear sky conditions.

The correlation coefficient, $\mathrm{R}$, of $0.968-0.997$ exist between the independent variable (diffuse fraction, $\mathrm{K}_{\mathrm{d}}$ ). This implies that the predictive models adequately estimated the observed values of DHI as a result of high positive correlation between the observed and predicted values of DHI under all sky conditions. This is comparable to the report in literature [9-10, 14-15]. However, the correlation coefficient was greatly lowered under clear sky conditions in the six tropical zones. This is because under clear sky conditions, $\mathrm{BHI}$ is greatly enhanced resulting in the reduction of $\mathrm{DHI}$ in the solar spectrum.

The coefficient of determination $\left(\mathrm{R}^{2}\right)$ is generally high for the six zones investigated in the study. This means that the regression line fit in the sets of data adequately. The value of coefficient of determination ranged from $0.937-0.997$. This implies that $93.7-$ $99.7 \%$ of the clearness index can be accounted using diffuse frac-
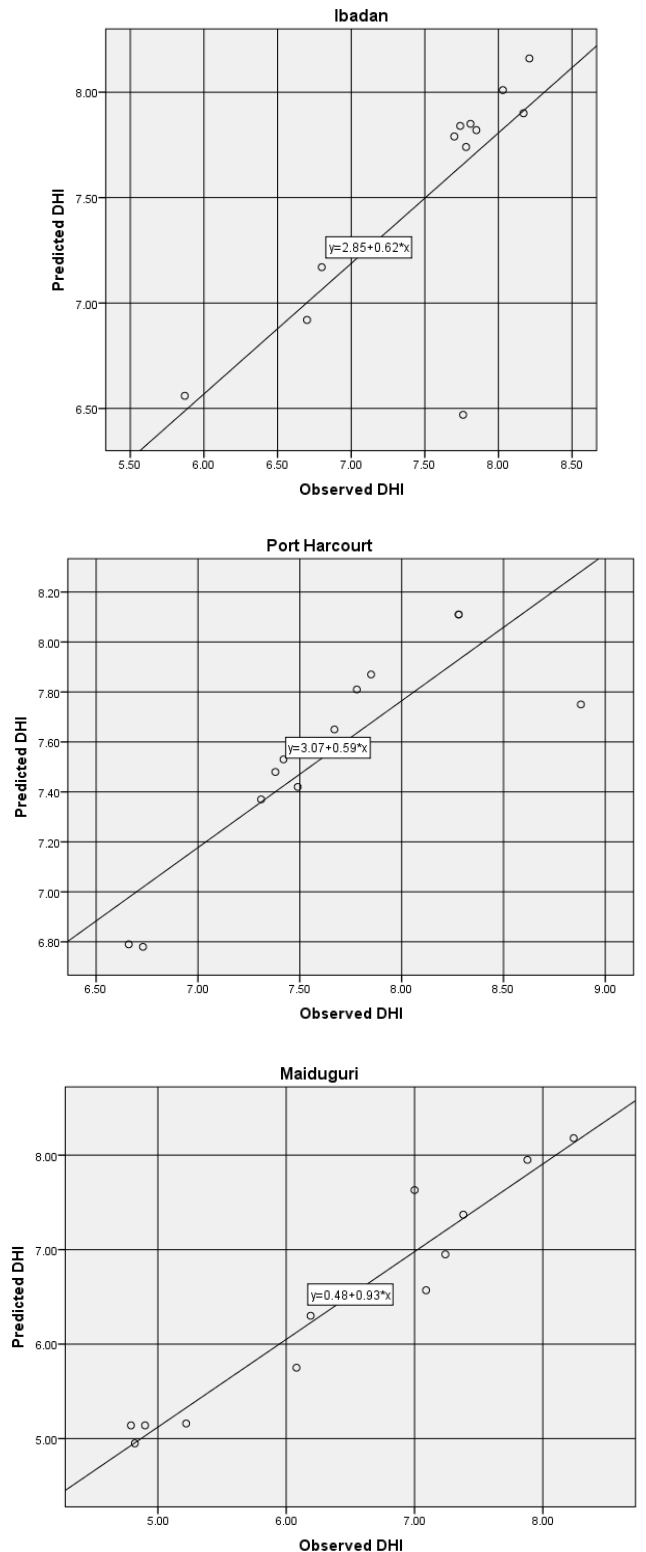

Fig. 3: Comparison Between Observed and Predicted Values (in $\mathrm{Mjm}^{-2} \mathrm{day}^{-1}$ ) of Diffuse Horizontal Irradiance (DHI) for Port Harcourt, Owerri, Ibadan,

Abuja, Miaduguri and Sokoto Stations Under All Sky Condition.

tion under all sky conditions. This values are within the range of the report of numerous researchers [9-10, 14-15]. However, the value was lowered under clear sky conditions because BHI was highly enhanced than DHI in the solar spectrum.

The adjusted coefficient of determination for all sky conditions recorded $0.923-0.996$ with the corresponding range 0.01237 0.00809 of standard error from the FNZSS of Sokoto to the FSZMS of Port Harcourt revealing that the proposed model fit for making generalization within the study area (Nigeria) other locations with comparable sky conditions to Nigeria while the values were lowered under clear sky conditions because BHI was greatly enhanced than DHI in the solar spectrum.

The scattered plot diagrams showing the variation of the observed and predicted DHI for the six stations are shown in Fig. 3. A linear curve fit with intercept of zero was applied to plot in order to produce the proposed model. The coefficient of determination of $0.9765,0.99044,0.99783,0.9913,0.9654$ and 0.946 respectively were recorded for Port Harcourt, Owerri, Ikeja, Abuja, Maiduguri and Sokoto. These values are within what is expected for a tropical site.
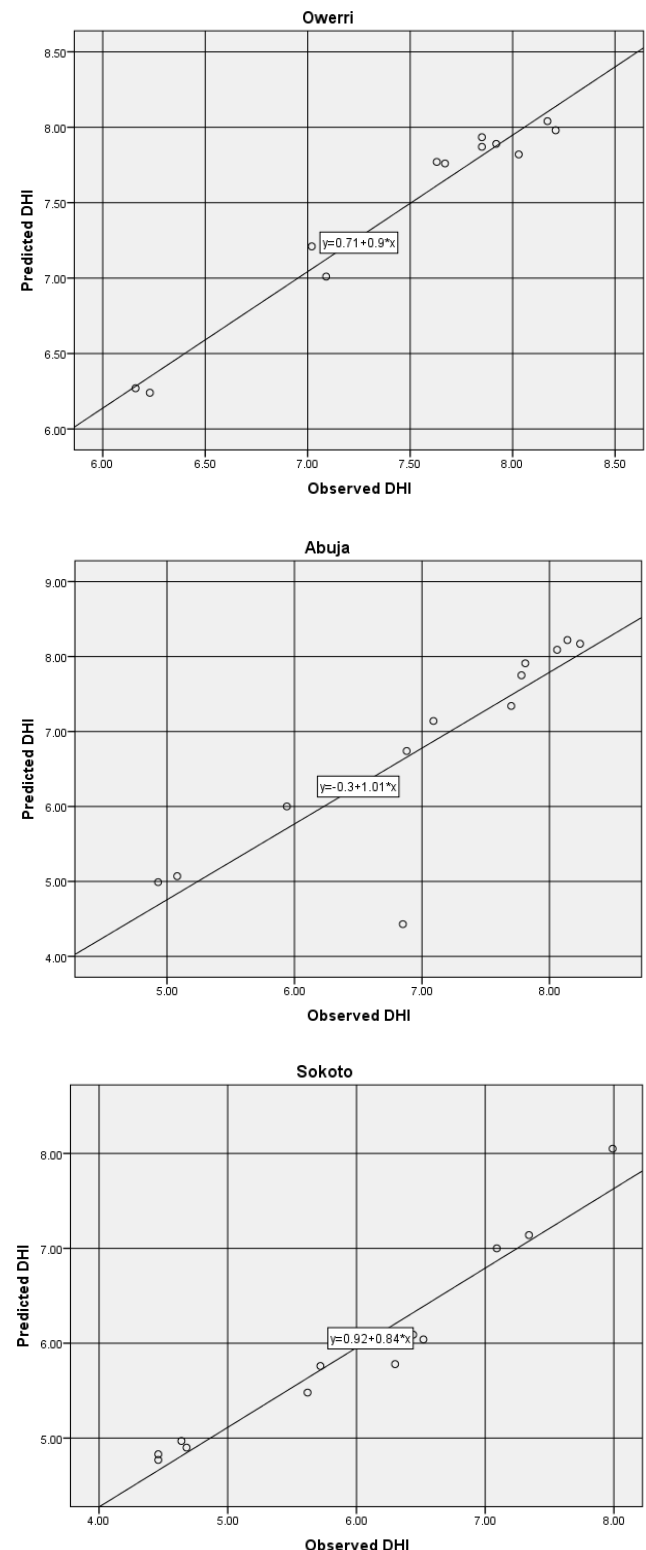
Table 4: Statistical Results for The Validation of the of Predicted (Model) Diffuse Horizontal Irradiation (DHI) in Terms of Their Capability for Estimating the Diffuse Horizontal Irradiation Under Various Sky Conditions for Port Harcourt, Owerri, Ibadan, Abuja, Maiduguri and Sokoto

\begin{tabular}{|c|c|c|c|c|c|c|c|c|}
\hline Stations & $\begin{array}{l}\text { Sky } \\
\text { Conditions }\end{array}$ & $b_{o}$ & $b_{1}$ & $\mathrm{~b}_{2}$ & $R$ & $R^{2}$ & $R_{a}^{2}$ & $\begin{array}{l}\text { Standard } \\
\text { Error }\end{array}$ \\
\hline Port Harcourt & $\begin{array}{l}\text { All Sky } \\
\text { Clear Sky }\end{array}$ & $\begin{array}{l}1.011 \\
-34.62\end{array}$ & $\begin{array}{l}-1.091 \\
122.42\end{array}$ & $\begin{array}{l}-0.195 \\
-106.44\end{array}$ & $\begin{array}{l}0.997 \\
0.783\end{array}$ & $\begin{array}{l}0.995 \\
0.612\end{array}$ & $\begin{array}{l}0.993 \\
0.526\end{array}$ & $\begin{array}{l}0.00809 \\
0.06860\end{array}$ \\
\hline Owerri & $\begin{array}{l}\text { All Sky } \\
\text { Clear Sky }\end{array}$ & $\begin{array}{r}0.987 \\
-13.81\end{array}$ & $\begin{array}{l}-1.003 \\
47.649\end{array}$ & $\begin{array}{l}-0.257 \\
-39.80\end{array}$ & $\begin{array}{l}0.997 \\
0.716\end{array}$ & $\begin{array}{l}0.993 \\
0.512\end{array}$ & $\begin{array}{l}0.991 \\
0.403\end{array}$ & $\begin{array}{l}0.00869 \\
0.08690\end{array}$ \\
\hline Ibadan & $\begin{array}{l}\text { All Sky } \\
\text { Clear Sky }\end{array}$ & $\begin{array}{l}0.942 \\
20.86\end{array}$ & $\begin{array}{l}-0.825 \\
-77.77\end{array}$ & $\begin{array}{r}-0.447 \\
73.75\end{array}$ & $\begin{array}{l}0.997 \\
0.656\end{array}$ & $\begin{array}{l}0.994 \\
0.430\end{array}$ & $\begin{array}{l}0.993 \\
0.304\end{array}$ & $\begin{array}{l}0.00804 \\
0.07984\end{array}$ \\
\hline Abuja & $\begin{array}{l}\text { All Sky } \\
\text { Clear Sky }\end{array}$ & $\begin{array}{l}0.981 \\
-49.95\end{array}$ & $\begin{array}{l}-1.020 \\
175.55\end{array}$ & $\begin{array}{l}-0.195 \\
-153.0\end{array}$ & $\begin{array}{l}0.999 \\
0.522\end{array}$ & $\begin{array}{l}0.997 \\
0.273\end{array}$ & $\begin{array}{l}0.996 \\
0.111\end{array}$ & $\begin{array}{l}0.00681 \\
0.10607\end{array}$ \\
\hline Maiduguri & $\begin{array}{l}\text { All Sky } \\
\text { Clear Sky }\end{array}$ & $\begin{array}{l}0.907 \\
29.75\end{array}$ & $\begin{array}{l}-0.721 \\
-96.05\end{array}$ & $\begin{array}{l}-0.456 \\
78.178\end{array}$ & $\begin{array}{l}0.998 \\
0.750\end{array}$ & $\begin{array}{l}0.996 \\
0.563\end{array}$ & $\begin{array}{l}0.971 \\
0.466\end{array}$ & $\begin{array}{l}0.01237 \\
0.05298\end{array}$ \\
\hline Sokoto & $\begin{array}{l}\text { All Sky } \\
\text { Clear Sky }\end{array}$ & $\begin{array}{l}2.132 \\
0.678 \\
\end{array}$ & $\begin{array}{l}-4.750 \\
-1.082 \\
\end{array}$ & $\begin{array}{l}2.852 \\
-\quad \\
\end{array}$ & $\begin{array}{l}0.968 \\
0.475 \\
\end{array}$ & $\begin{array}{l}0.937 \\
0.208 \\
\end{array}$ & $\begin{array}{l}0.923 \\
0.129 \\
\end{array}$ & $\begin{array}{l}0.01511 \\
0.05089 \\
\end{array}$ \\
\hline
\end{tabular}

\subsection{Model performance}

The performance of the model is evaluated and compared using statistical parameters $\mathrm{R}, \mathrm{R}^{2}, R_{a}^{2}$, standard error of the estimation,

MBE, MPE and RMSE for each zone. The summary of the error is presented in Tables 5 and Fig. 4. The mean error parameters were observed to be vary from one zone to another and from one month to another. This could be attributed to the influence of clearness index, latitude, presence of heavy smog, rainy and other atmospheric parameters on each zone. It can also be noted that the prediction of DHI can be evaluated with reasonable accuracy with the model in the six zones studied.

From Table 5, it is obvious that the MBE at Port Harcourt, Owerri, Ibadan, Abuja, Maiduguri and Sokoto are close to zero ranging from 0.00005 to 0.03992 indicating that the model is efficient for estimating DHI adequately for any tropical ecological zone in Nigeria and locations with similar climatological conditions. It is also clear that MPE for the six tropical ecological sites studied is equally close to zero implying that the model best predicted the observed values of DHI in the stations analyzed. RMSE indicates that there is error in the predicted data of the model when compared to the observed data. This error is close to zero ( $0.3022-$ 0.8908 ) in the six tropical sites evaluated, revealing that the model is most suitable for the zones. From the statistical test results of the six tropical ecological zones (Table 5), it can be seen that the six tropical ecological zones has the values of standard error of estimation, MBE, MPE and RMSE very close to zero, and $\mathrm{R}, \mathrm{R}^{2}$, and $R_{a}^{2}$ values very near to 1.0 as recommended by Ituen et al. [23]. Therefore, it can be said that the model is very suitable for estimating monthly mean DHI for six tropical ecological zones analysed in this research paper and thus, could be employed for predicting monthly mean daily $\mathrm{DHI}$ in any station across the globe that has similar climatological characteristics with Nigeria.

Table 5: A) Statistical Results for the Validation of the Predictive Models of Diffuse Horizontal Irradiation in Terms of Their Capability for Estimating the Diffuse Horizontal Irradiation under All Sky Conditions for Southern Tropical Zones (Port Harcourt, Owerri And Ibadan)

\begin{tabular}{|c|c|c|c|c|c|c|c|c|c|}
\hline \multirow[b]{2}{*}{ Months } & \multicolumn{2}{|c|}{ Port Harcourt } & \multirow[b]{2}{*}{ RMSE } & \multicolumn{3}{|l|}{ Owerri } & \multicolumn{2}{|l|}{ Ibadan } & \multirow[b]{2}{*}{ RMSE } \\
\hline & MBE & MPE & & MBE & MPE & RMSE & MBE & MPE & \\
\hline JANUARY & -0.0039 & -0.0574 & 0.0134 & -0.0014 & -0.0219 & 0.0047 & 0.0015 & 0.0259 & 0.0047 \\
\hline FEBUARY & 0.0063 & 0.0797 & 0.0207 & 0.0071 & 0.1003 & 0.0246 & 0.0047 & 0.0696 & 0.0246 \\
\hline MARCH & 0.0143 & 0.1718 & 0.0493 & 0.0170 & 0.2114 & 0.0588 & 0.0144 & 0.1849 & 0.0588 \\
\hline APRIL & 0.0141 & 0.1707 & 0.0490 & 0.0186 & 0.2272 & 0.0646 & 0.0230 & 0.2820 & 0.0646 \\
\hline MAY & -0.0017 & -0.0221 & 0.0060 & -0.0020 & -0.0258 & 0.0070 & -0.0012 & -0.0155 & 0.0070 \\
\hline JUNE & -0.0092 & -0.1236 & 0.0317 & -0.0112 & -0.1469 & 0.0388 & -0.0121 & -0.1568 & 0.0388 \\
\hline JULY & -0.0048 & -0.0652 & 0.0165 & -0.0078 & -0.1011 & 0.0269 & -0.0040 & -0.0505 & 0.0269 \\
\hline AUGUST & 0.0012 & 0.0154 & 0.0041 & 0.0022 & 0.0278 & 0.0076 & 0.0075 & 0.0932 & 0.0076 \\
\hline SEPTEMBER & 0.0116 & 0.1467 & 0.0401 & 0.0107 & 0.1314 & 0.0372 & 0.0046 & 0.0562 & 0.0372 \\
\hline OCTOBER & -0.0027 & 0.0343 & 0.0092 & -0.0070 & -0.0892 & 0.0242 & -0.0134 & -0.1731 & 0.0242 \\
\hline NOVEMBER & -0.0079 & -0.1073 & 0.0274 & -0.0161 & -0.2298 & 0.0559 & -0.0033 & -0.0495 & 0.0559 \\
\hline DECEMBER & -0.0101 & -0.1609 & 0.0371 & -0.0097 & -0.1569 & 0.0334 & -0.0108 & -0.1879 & 0.0334 \\
\hline AVEAGE & 0.0005 & 0.0011 & 0.0254 & 0.00005 & -0.0061 & 0.0319 & 0.0009 & 0.0065 & 0.0319 \\
\hline SUM & 0.0062 & 0.0136 & 0.3045 & 0.0005 & -0.0733 & 0.3839 & 0.0110 & 0.0785 & 0.3839 \\
\hline
\end{tabular}

Table 5: B) Statistical Results for the Validation of the Predictive Models of Diffuse Horizontal Irradiation in Terms of Their Capability under All Sky Conditions for Estimating the Diffuse Horizontal Irradiation for Northern Tropical Zones (Abuja, Maiduguri and Sokoto)

\begin{tabular}{|c|c|c|c|c|c|c|c|c|c|}
\hline \multirow[b]{2}{*}{ Months } & \multicolumn{3}{|l|}{ Abuja } & \multicolumn{3}{|c|}{ Maiduguri } & \multicolumn{3}{|l|}{ Sokoto } \\
\hline & MBE & MPE & RMSE & MBE & MPE & RMSE & MBE & MPE & RMSE \\
\hline JANUARY & -0.0046 & -0.0937 & 0.0160 & -0.0202 & -0.4120 & 0.0699 & -0.0270 & -0.5807 & 0.0934 \\
\hline FEBUARY & -0.0049 & -0.0832 & 0.0171 & 0.0052 & 0.1000 & 0.0181 & -0.0183 & -0.3919 & 0.0635 \\
\hline MARCH & 0.0110 & 0.1594 & 0.0380 & 0.0279 & 0.4589 & 0.0967 & 0.0109 & 0.1948 & 0.0379 \\
\hline APRIL & 0.0307 & 0.3986 & 0.1064 & 0.0433 & 0.6099 & 0.1498 & 0.0435 & 0.6906 & 0.1507 \\
\hline MAY & 0.0025 & 0.0317 & 0.0085 & 0.0221 & 0.3057 & 0.0766 & 0.0397 & 0.6098 & 0.1376 \\
\hline JUNE & -0.0084 & -0.1074 & 0.0291 & 0.0009 & 0.0128 & 0.0033 & 0.0291 & 0.4524 & 0.1010 \\
\hline JULY & -0.0025 & -0.0304 & 0.0085 & -0.0058 & -0.0730 & 0.0199 & 0.0169 & 0.2299 & 0.0585 \\
\hline AUGUST & 0.0060 & 0.0723 & 0.0206 & 0.0054 & 0.0651 & 0.0186 & -0.0045 & -0.0562 & 0.0155 \\
\hline SEPTEMBER & -0.0067 & -0.0822 & 0.0232 & -0.0029 & -0.0380 & 0.0099 & 0.0080 & 0.1123 & 0.0276 \\
\hline OCTOBER & -0.0037 & -0.0526 & 0.0129 & -0.0100 & -0.1665 & 0.0357 & -0.0029 & -0.0509 & 0.0101 \\
\hline NOVEMBER & 0.0003 & 0.0061 & 0.0011 & -0.0108 & -0.2234 & 0.0373 & -0.0256 & -0.5741 & 0.0888 \\
\hline DECEMBER & 0.0057 & 0.1268 & 0.0198 & -0.0291 & -0.6082 & 0.1009 & -0.0306 & -0.6863 & 0.1061 \\
\hline AVEAGE & 0.0021 & 0.0288 & 0.0251 & 0.0022 & 0.0026 & 0.0531 & 0.0033 & -0.0042 & 0.0742 \\
\hline SUM & 0.0253 & 0.3454 & 0.3011 & 0.0258 & 0.0314 & 0.6369 & 0.0400 & -0.0502 & 0.8908 \\
\hline
\end{tabular}




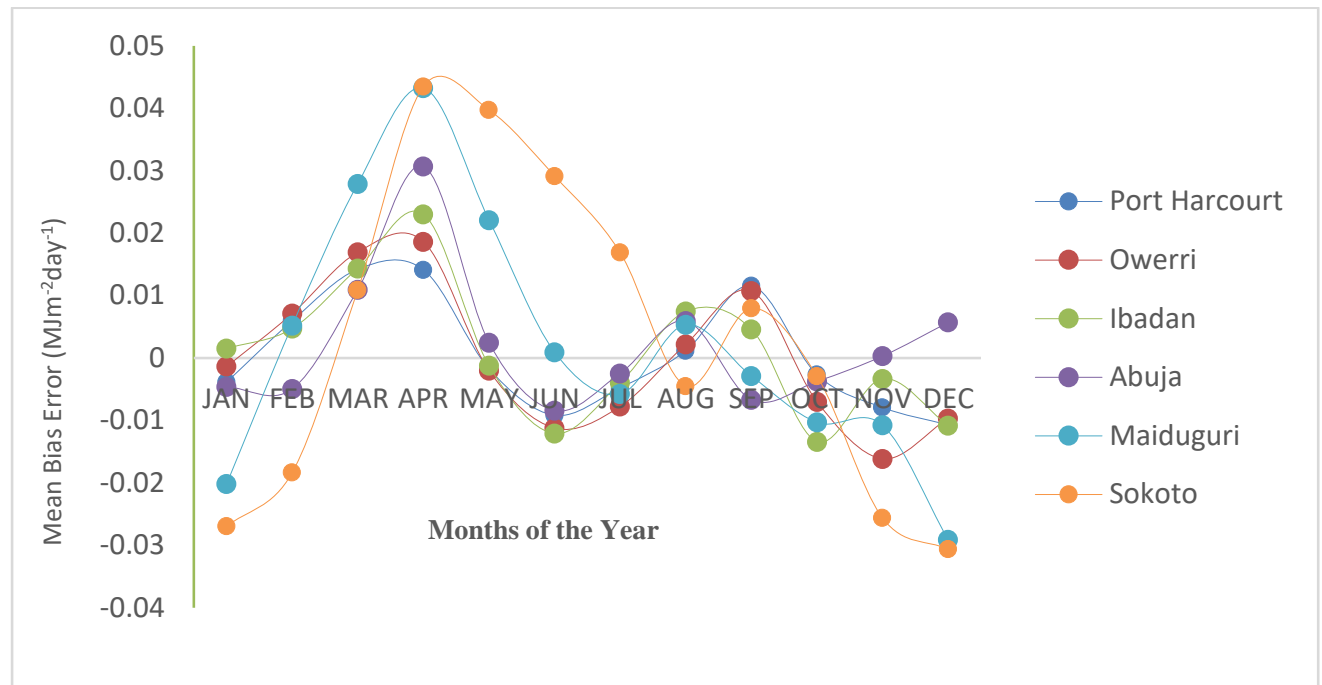

Fig. 4: A) Variations of Mean Bias Error Over Port Harcourt, Owerri, Ibadan, Abuja, Maiduguri and Sokoto under All Sky Condition.

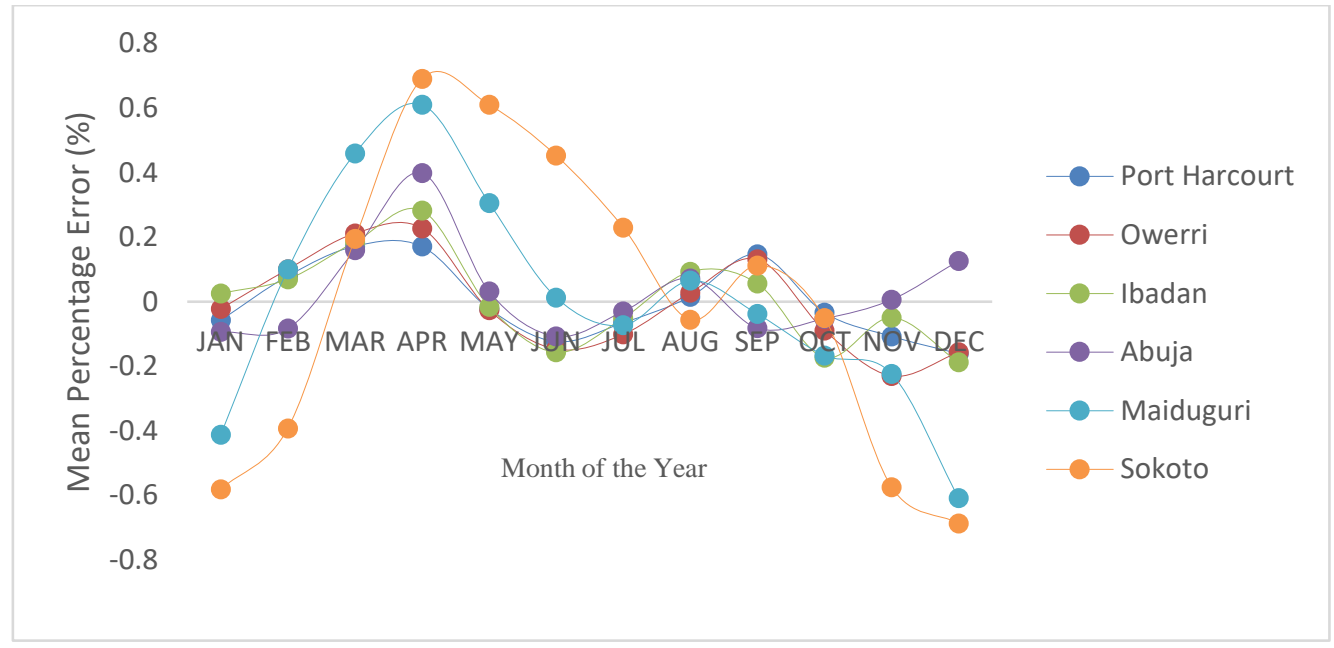

Fig. 4: B) Variation of Mean Percentage Error for Port Harcourt, Owerri, Ibadan, Abuja, Maiduguri and Sokoto under All Sky Condition.

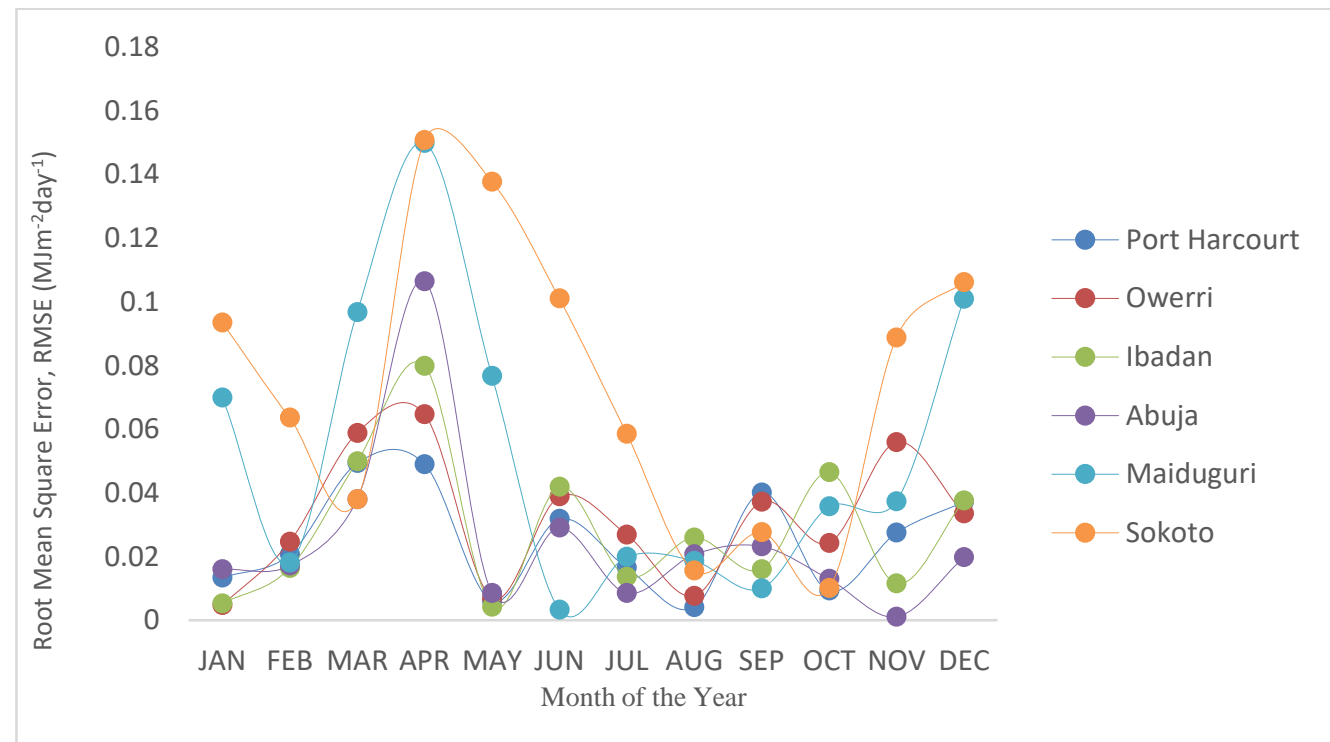

Fig. 4: C) Variation of RMSE for Port Harcourt, Owerri, Ibadan, Abuja, Maidugurri and Sokoto under All Sky Condition.

\section{Conclusion}

The analysis of the influence of clearness index on diffuse fraction based on the radiation data recorded for Port Harcourt, Owerri, Ibadan, Abuja, Maiduguri and Sokoto representing the six tropical ecological zones in Nigeria were investigated for all sky condition and clear sky. It was revealed that the absorption of DHI in the GHI portion of the solar spectrum is greatly enhanced in the Southern tropical zones as a result of high relative humidity and prolonged rainy season, presence of heavy smog and low clearness thereby increasing the diffuse fraction in the zone. While the absorption of DHI in the GHI portion of the solar spectrum lowered in the Northern tropical zones a result of high influence of pro- 
longed dry season, high clearness index, low relative humidity, low smog that decreases the DHI thereby reducing the diffuse fraction in the region. This research paper is the first attempt to qualify DHI parameters in the six tropical ecological zones in Nigeria; thus our model can be used to estimate DHI parameters for locations with similar climatological condition where GHI data are readily available.

\section{Acknowledgement}

Our thanks go to the NASA Langley Research Center Atmospheric Science Data Center Surface meteorological and Solar Energy (SSE) web portal supported by the NASA LaRC POWER Project for the data used for this research paper. We also wish to thank all the authors cited in this paper for their research works that has made this research possible.

\section{References}

[1] McCree, K.J. (1972). Test of current definitions of photosynthetically active radiation against leaf photosynthesis data. Agric. For Meteorol. 10, 443-453. https://doi.org/10.1016/0002 1571(72)90045-3.

[2] Wang, Q., Kakubari Y., Kubota M. (2007). Variation of PAR to global solar radiation ratios along altitude gradient in Naeba Mountain. Theo. and Appl. Clima., 87, 239-253 https://doi.org/10.1007/s00704-005-0220-6.

[3] El-Sebaii, A.A., Al-Agel F. (2012). Estimation of horizontal diffuse solar radiation from common meteorological parameters: a case study for Jeddah, Saudi Arabia, International Journal of Ambient Energy, $1-8$

[4] Bhattacharya, A.B, Kar, S.K., Bhattacharya, R. (1996). Diffuse solar radiation and associated meteorological parameters in India Ann. Geophysi., 14, 1051-1059. https://doi.org/10.1007/s005850050366.

[5] Page, J.K. (1960). The estimation of monthly mean values of daily total short-wave radiation on vertical and inclined surfaces from sunshine records for latitude $40 \mathrm{oN}$ and $40 \mathrm{oS}$. Proceedings UN Conferenceon New Sources of Energy, 1961, Rome, Italy, United Nations, 4, 598: 378-390.

[6] Iqbal M. (1980). Prediction of hourly diffuse solar radiation from measured hourly global radiation on a horizontal surface. Solar Energ. 24, 491-503. https://doi.org/10.1016/0038-092X(80)90317-5.

[7] Jacovides C.P. Boland, J., Asimakopoulos, D.S. (2010). Comparing diffuse radiation models with one predictor for partitioning incident PAR radiation into its diffuse component in the Eastern Mediterranean basin, Renew. Energy, 35, 1820-1827. https://doi.org/10.1016/j.renene.2009.11.015.

[8] Liu, B.V.H. Jordan, R.C. (1979). The interrelationship and characteristics distribution of direct, diffuse and total solar radiation, Solar Radiation, 22, 87-90.

[9] Mohammed A.A.A. (2010). The anaylsis of the characteristics of the solar radiation climate of the daily global radiation and diffuse radiation in Amman, Jordan, International Journal of Renewable Energy, 5, 23-38.

[10] Theophile, L., Rene, T. (2013). Estimation of diffuse solar radiation in area between $50 \mathrm{~N}$ and $10 \mathrm{oN}$ of Cameroun, Natural Resources, 4, 279-285 https://doi.org/10.4236/nr.2013.43035.

[11] Basharat, J. \& Abid T.S. (2017). Generalized models for estimation of diffuse solar radiation based on clearness index and sunshine duration in India: Applicability under different climate zones. Journal of Atmospheric and Solar-Terrestrial Physics, 157: 16-34.

[12] Martinez-Lozano, J.A., Utrillas M.P., Gomez, V. (1994). Estimation of the diffuse irradiation from global solar irradiation. Daily and monthly average daily values. Renewable Energy, 4: 95-100 https://doi.org/10.1016/0960-1481(94)90069-8.

[13] Nfaoui, H. Buret, J. (1993). Estimation of daily and monthly direct, diffuse and global solar radiation in Rabat (Morocco). Renewable Energy, 3: 923-930 https://doi.org/10.1016/0960-1481(93)90052-I.

[14] Jain, P.C. (1990). Model for diffuse and global irradiation on horizontal surfaces. Solar Energy, 45: 301-308 https://doi.org/10.1016/0038-092X(90)90015-5.

[15] Ibrahim, S.M.A. (1985). Diffuse solar radiation in Cairo, Egypt. Energy Conversion and Management, 25: 69-72 https://doi.org/10.1016/0196-8904(85)90072-X
[16] Erbs, D.G., Klein, S.A. Duffie, J.A. (1982). Estimation of the diffuse radiation fraction for hourly, daily and monthly average global radiation. Solar Energy, 28: 293-302 https://doi.org/10.1016/0038092 X(82)90302-4

[17] Nwokolo, S.C. (2017). A comprehensive review of empirical models for estimating global solar radiation in Africa. Renewable and Sustainable Energy Reviews, 78: 955-995 https://doi.org/10.1016/j.rser.2017.04.101.

[18] Nwokolo, S.C., \& Ogbulezie, J.C., (2017a). A Quantitative Review and Classification of Empirical Models for Predicting Global Solar Radiation in West Africa. Beni-Suef University Journal of Basic and Applied Sciences, (In Press).

[19] Nwokolo, S.C., \& Ogbulezie, J.C. (2017b). A single hybrid parameter-based model for calibrating Hargreaves-Samani coefficient in Nigeria. International Journal of Physical Research, 5(2): 49-59 https://doi.org/10.14419/ijpr.v5i2.8042.

[20] Willmott, C.J. (1981). On the validation of models. J. Phys. And Geogr. 2, 184-194.

[21] Burari, F.W. (2004). Correlation of global and diffuse solar radiation components with meteorological parameters for Bauchi, Jolorn, 5(1): 49-55.

[22] Nwokolo, S.C., Ogbulezie, J.C., Toge, C.K., John-Jaja, S.A. (2016) Modeling the influence of relative humidity on photosynthetically active radiation from global horizontal irradiation in six tropical ecological zones in Nigeria. New York Science Journal, 9(11): 4055.

[23] Ituen, E.E., Esen, N.U., Nwokolo, S.C., Udo, E.G. (2012). Prediction of global solar radiation using relative humidity, maximum temperature and sunshine hours in Uyo, in the Niger Delta Region, Nigeria. Advances in Applied Science Research, 4, 1923-1937. 